"Can I leave?" he pleaded, having already thought better of the request.

"You are free to go. A hospital is no prison," I replied. "But my advice is to put first things first."

And so he stayed, and we listed his condition as "serious." Today it was downgraded to "guarded," and we shipped him for a cardiac catheterisation, during which a dislodged plaque triggered the fatal complication.
Time is not unlimited. Will we take stock of conditions and adapt? This is what nature and our patients keep asking us. Adaptation is one of life's insistent demands, one that could yet save us from the lofty sentiments and fatal flaws of our expeditionary careers.

Competing interests: None declared.

doi 10.1136/bmj.39057.524792.BE

\title{
The challenging isle: a walk through Soho
}

\author{
Nick Black
}

To learn about the history of health care in England, there is no better place than London. It was in London that most of the key developments in health care took place and it was there that the key battles over healthcare policies were fought, where conflicts were resolved, and where many innovations occurred. Some of the important buildings in the history of health care have been destroyed, but many still remain.

Walking London's Medical History aims to inspire and educate through a series of seven walks in central London. ${ }^{1}$ These walks help to tell the story of how health services developed from medieval times to the present day. The walks also help to preserve our legacy by informing us of the original function of healthcare buildings as increasingly they are being converted into hotels, offices, residences, and shops. Finally, the walks help to increase our understanding of the challenges to improving health care in the 21 st century. To give you a flavour of the walks, let us consider the one through Soho.

At the heart of London lies an island, a foreign land in a sea of Englishness. Since its development in the 17 th century, Soho has always been different from the districts surrounding it. The region has challenged and threatened the rest of London while at the same time enticed and nourished it. The reasons are bound up with its origins.

\section{Soho, a brief history}

Until the 1660 s the Soho area was hunting country. Development close to London was forbidden for fear of contagious diseases spreading to within the city walls. When the great fire of 1666 left around 100000 people homeless, however, this restriction had to be abandoned as refugees flocked west in search of new beginnings. Although Soho was born out of an urgent necessity, it rapidly became fashionable.

Development started in the south in the 1670s with Old Compton Street and Golden Square, spreading north by way of Dean Street and Wardour Street to Soho Square in the 1680 s. Property was bought by wealthy city merchants wanting to be closer to the royal palaces of Whitehall, Westminster, and St James. By 1700 up to 80 titled citizens, 27 members of parliament, and many foreign ambassadors and envoys resided in Soho.

Meanwhile the first of a succession of refugees arrived seeking sanctuary, tolerance, and opportuni- ties. After revocation of the Edict of Nantes in 1685 about 15000 Huguenots fled to avoid religious persecution. By 1711 almost half of the parish of Soho was French. The air of freedom and non-Englishness created by the politicised Huguenots encouraged people from other countries to settle in Soho.

By the mid-1700s the nobility and gentry started to shift further west to Mayfair and beyond. In the 1760s they were partly replaced by Greeks escaping persecution from Turkish occupiers and in the 1790s by more French, this time fleeing from their own revolution. Little wonder the area was still referred to as petty France in the 1840s. Still more foreigners arrived: political refugees from Germany and from Italy after failed revolutions and Russian and Polish Jews escaping the pogroms. By 1900 Soho must have been one of the most cosmopolitan urban areas in the world, for in addition there were people from Switzerland, Belgium, Sweden, Austria, Holland, Spain, Hungary, Denmark, and the Americas. From the 1920s onwards they were joined by Chinese migrants.

New arrivals may have had little wealth but they contributed their food, art, and energy thus creating the vibrant and convivial atmosphere of Soho. This in turn attracted the unorthodox-artists, revolutionaries, writers, and musicians-Marx, Casanova, Canaletto, Marat, Hogarth, Blake, De Quincey, Dryden, Garibaldi, and Mozart, to name but a few. With the artistic and intellectual freedom these people brought came sexual liberalism. Alongside Soho's reputation for international food and dining came the more notorious reputation from 1800 for night clubs, erotic shows, and prostitution, fuelled by a ready supply of impoverished residents desperate for work.

Although the men of the governing classes in their West End homes were happy to enjoy what was on offer in the brothels and molly houses of Soho, they wanted the area contained. In 1816-24, in a rare act of the Crown, 700 properties were swept away to create Regent Street, a boundary between the nobility of Mayfair and the people of Soho.

An unintended but lasting benefit of such overt social engineering is that Soho is the best preserved area of London. Its street pattern has hardly altered in 300 years. Buildings of domestic simplicity on a human scale have survived, with few high rise developments. Soho remains an island, a foreign land entered from Oxford Street to the north, Charing Cross Road to the east, Regent Street to the west, and Leicester Square to
London School of Hygiene and Tropical Medicine, London London

Nick Black professor of health services research

nick.black@ lshtm.ac.uk

BMJ 2006;333:1325-6 


\section{Great Windmill Street School of Anatomy}

Just off Shaftesbury Avenue, beside the Windmill Theatre, is a four storey red painted brick façade. This is all that remains of the first and most famous private anatomy school in London. It was established by William Hunter, a Scottish surgeon, within months of the Company of Barber-Surgeons splitting in 1745. Until then the Barber-Surgeons' Hall and the Royal College of Physicians were the only places where dissection of corpses was permitted.

For 22 years the school was based in houses in Covent Garden and the Haymarket. In 1768 Hunter commissioned a purpose built school, the façade of which is visible today. The school included an anatomy theatre and a museum to house the thousands of anatomical preparations covering the animal kingdom that Hunter had amassed.

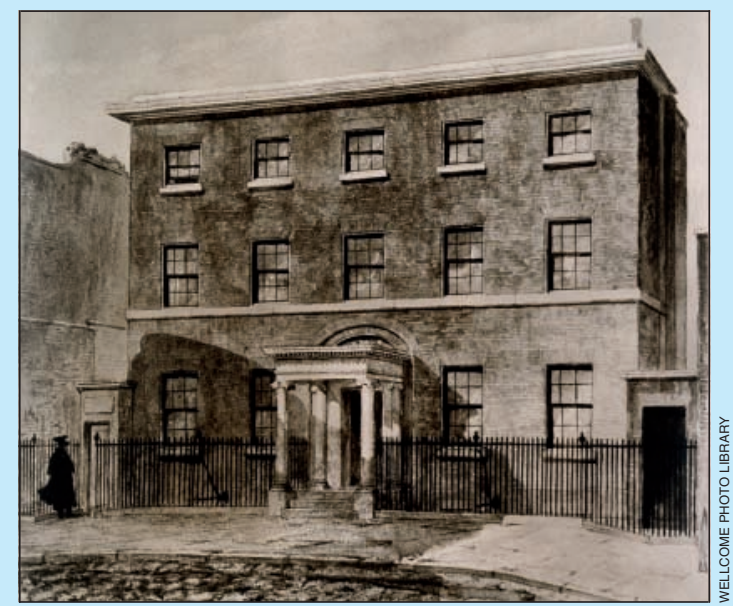

Great Windmill Street School of Anatomy as it looked in its heyday when it was the leading theatre of anatomy in London

The school was immensely popular, with 100 students often present. They were taught through the dissection of hanged criminals and although this practice was legal it remained controversial and the students were discouraged from discussing it with members of the public. The audiences were not restricted to aspiring surgeons. At the time a knowledge of anatomy was "very properly considered a necessary accomplishment to a gentleman and indispensable to the lawyer."

The demand for corpses encouraged resurrectionists whose activities had horrendous consequences. In 1784 John Sheldon, who ran a private anatomical school in Great Queen Street, was horrified when his sister's body was delivered to him. The anatomists' demand for bodies, particularly young healthy ones, and the prices they were prepared to pay, led to murder. While Edinburgh had Burke and Hare, London had Bishop and Williams.

The importance of the school in Great Windmill Street was immense as many other schools were set up by Hunter's pupils. The school continued to prosper after Hunter's death in 1783. By the 1830s, however, the voluntary general hospitals had established their own medical schools, partly because education was shifting from the dissection room to the wards and partly

because teaching was a lucrative activity. Hunter's school closed in 1836 and the building became a French restaurant before being incorporated into the Lyric Theatre in 1887.

the south. The contrast between Mayfair and Soho has persisted and can still be felt on crossing Regent Street. For over 200 years Soho has offered visitors informality and excitement, be it from food around the world, entertainment, or sex.

\section{Somewhere to take risks}

The enduring character of Soho helped shape its health services. The atmosphere has encouraged individuality, creativity, and entrepreneurship, the main theme of this walk. Soho is somewhere to take risks and to challenge orthodoxy.
The departure of the nobility in the mid-1700s provided the opportunity for members of the newly established professions to move in and start up commercial and charitable enterprises: John Hunter, who transformed surgery; Hunter's brother, William, who established the first anatomy school (box); George Armstrong who established the first dispensary for sick children in England; and John Lind who founded the second only general dispensary in London. They were followed in the 19th century by John Harrison Curtis, a naval surgeon with no formal medical qualifications, who established the first ear hospital in England, and Benjamin Golding, a young doctor, who established what was to become Charing Cross Hospital.

The second theme of this walk arises from the consequences of sexual liberalism. Venereal disease, the "foul disease," existed in all social stratums of London. With the exception of the Middlesex Hospital (from 1803) and the Royal Free Hospital (from 1828), general hospitals refused admission of patients with venereal diseases, fearing contagion. By 1850 realisation of the need for services to meet this challenge resulted in the establishment of three specialist hospitals in Soho that openly treated venereal diseases: Protheroe Smith moved the first hospital exclusively for diseases of women to Soho Square after nine years in Red Lion Square; the Lock Hospital, the first hospital in London for men with venereal diseases, was established in Dean Street; and John Laws Milton set up St John's Hospital for skin diseases, many of which would have been venereal in origin. Additional services, particularly for female prostitutes, were provided by another Soho institution, the Hôpital et Dispensaire Français.

The third theme of this walk is the way medical entrepreneurship has driven change in health care. In addition to establishing specialist hospitals, medical practitioners (surgeons in particular) set up private anatomy schools. By 183621 schools existed in London, three of them in Soho, including the first and most prestigious, in Great Windmill Street (box).

The social character of Soho is well illustrated by two towering figures in the history of health care, one of whom you will encounter at the start of the walk and the other at the end. Shortly after entering Soho from Oxford Street you will see the home of Mary Seacole, daughter of a free black Jamaican slave who, although rejected by the authorities, nursed wounded British soldiers on the battlefield in the Crimean war. She personified Soho-relaxed and openly loving, with a joie de vivre. As you reach the southern and western parts of Soho, you return to the world of the establishmentthe former homes of the Royal Dental Hospital and the Royal College of Physicians. And there, amid the gentlemen's clubs of St James's, is a grand monument to the Crimean war complete with a statue of Florence Nightingale, the daughter of wealthy middle class parents but who, in contrast to Seacole, was anguished and emotionally retentive. The bas reliefs on the monument show nurses tending the injured, but there is no sign of "Mother Seacole."

Competing interests: None declared.

Black N. Walking London's medical history. London: Royal Society of Medicine Press, 2006.

doi 10.1136/bmj.39056.530995.BE 